\title{
HIPNOTERAPI SEBAGAI PILIHAN UTAMA MANAJEMEN NYERI PADA INTRAOPERATIF SIRKUMSISI
}

\author{
Iwan Samsugito ${ }^{1}$, Mayusef Sukmana ${ }^{2 *}$, Muhammad Aminuddin ${ }^{3}$, Sholichin ${ }^{4}$, \\ Ediyar Miharja ${ }^{5}$, Dwi Nopriyanto ${ }^{6}$, Syukma Rhamadani Faizal Nur ${ }^{7}$, Bahtiar $^{8}$, \\ Iskandar Muda ${ }^{9}$, Siti Rahmadhani ${ }^{10}$ Isma Zul Abdillah Jaya ${ }^{11}$, Siti Riyani ${ }^{12}$ \\ Enda Maimia Taesa Allison ${ }^{13}$ \\ ${ }^{1-13}$ Universitas Mulawarman
}

Email korespondensi: 200801sukmana@gmail.com

Disubmit: 07 Juli 2021 Diterima: 09 Agustus $2021 \quad$ Diterbitkan: 01 Februari 2022 DOI: https://doi.org/10.33024/jkpm.v5i2.4647

\begin{abstract}
ABSTRAK
Masalah yang terjadi pada sirkumsisi adalah nyeri akibat penyuntikan. Jika nyeri dapat dihilangkan proses sirkumsisi akan berjalan dengan lancar. Pilihan utama terapi komplementer dalam mengatasi nyeri intraoperatif adalah hipnoterapi. Tujuan pengabdian masyarakat adalah menghilangkan nyeri saat penyuntikan anestesi sehingga anak anak yang dilakukan sirkumsisi merasa nyaman dan senang. Metode yang dijalankan meliputi: protocol kesehatan, penjelasan hipnoterapi, melakukan hipnoterapi, evaluasi hipnoterapi dan pelaksanaan penyuntikan untuk sirkumsisi. Hasil yang didapat rata-rata anak-anak mengatakan tidak merasakan nyeri saat disuntik, orang tua senang melihat anaknya berani disuntik. Pengabdian masyarakat tentang penerapan hipnosis saat intraoperative sirkumsisi mampu menghilangkan nyeri saat penyuntikan obat anestesi. Diharapkan hipnosis dapat diterapkan saat pelaksanaan sirkumsisi.
\end{abstract}

Kata Kunci: Sirskumsisi, Khitan, Sunat, Hipnoterapi

\begin{abstract}
The problem that occurs in circumcision is pain due to injection. If the pain can be eliminated the circumcision process will run smoothly. The main choice of complementary therapy in dealing with intraoperative pain is hypnotherapy. The purpose of community service is to relieve pain when injecting anesthesia so that children undergoing circumcision feel comfortable and happy. The methods used include: health protocols, explanation of hypnotherapy, performing hypnotherapy, evaluation of hypnotherapy and administering injections for circumcision. The results obtained on average said that children did not feel pain when injected, parents were happy to see their children dared to be injected. Community service about the application of hipnosis during intraoperative circumcision is able to relieve pain during injection of anesthetic drugs. It is hoped that hipnosis can be applied during circumcision
\end{abstract}

Keyword: Circumcision, Khitan, Sunat, Hypnotherapy 


\section{PENDAHULUAN}

Sirkumsisi atau sunat merupakan suatu keharusan yang dilakukan oleh anak pria yang beragama islam karena perintah agama dengan tujuan membersihkan alat kelamin pria (penis) dari kotoran atau smegma sehingga dapat mencegah penyakit cancer pada penis atau serviks pasangan (istri), penyakit menular seksual, fimosis dan menjaga kebersihan penis ( RS. Sarjito ). Sirkumsisi merupakan tindakan yang memerlukan persiapan satu diantaranya adalah persiapan tindakan anestesi. Selama sirkumsisi rasa nyeri akan dirasakan hanya pada penyuntikan anestesi(Wahyuni Hesti, Setiawaty, 2015), (Syamsul, 2019). Nyeri yang terjadi saat prosedur penyuntikan anestesi dapat membuat anak takut untuk dilakukan sirkumsisi, jika nyeri saat penyuntikan anestesi bisa dihilangkan maka sirkumsisi bisa berjalan dengan nyaman. Perlunya penerapan manajemen nyeri yang mantap dalam mengatasi nyeri saat penyuntikan anestesi. Teknik yang bisa dilakukan untuk mengatasi nyeri adalah hipnoterapi(Samsugito, 2020).

Hipnoterapi adalah suatu upaya untuk membuat seseorang mengalami kondisi rileks dan keadaan saat sangat mudah menerima sugesti(Cahyadi, 2017) dan hipnosis adalah suatu kondisi pikiran saat fungsi analisis logis pikiran di reduksi sehingga memungkinakan individu masuk ke dalam kondisi bawah sadar(Fachri AH, 2008). Penerapan hipnosis untuk mengatasi nyeri sudah lama dilakukan namun di Indonesia belum begitu popular penerapannya. Hipnosis yang diterapkan pada saat penyuntikan anestesi infiltrasi pada gusi gigi pada anakanak dapat menurunkan intensitas nyeri(Soma Arabzade Moghadam, Fayegh Yousefi, 2021), (Birnie, Kathryn and Noel, Melanie and Parker, Jennifer and Chambers, Christine and Uman, Lindsay and Kisely, Steve and McGrath, 2014). Libeault mengatakan hipnosis dapat mengurangi nyeri karena sugesti yang diberikan menyebabkan pikiran sadar seseorang mengabaikan perasaan nyeri akibatnya seseorang terfokus pada satu hal yang disugestikan(Fachri AH, 2008). Tujuan pengabdian masyarakat adalah menghilangkan nyeri saat penyuntikan anestesi sehingga anak-anak yang dilakukan sirkumsisi agar merasa nyaman dan senang

\section{MASALAH}

Nyeri saat penyuntikan anestesi saat sirkumsisi dapat membuat anak takut untuk disirkumsisi dan dapat menimbulkan ketakutan pada rekan rekannya yang menunggu giliran.

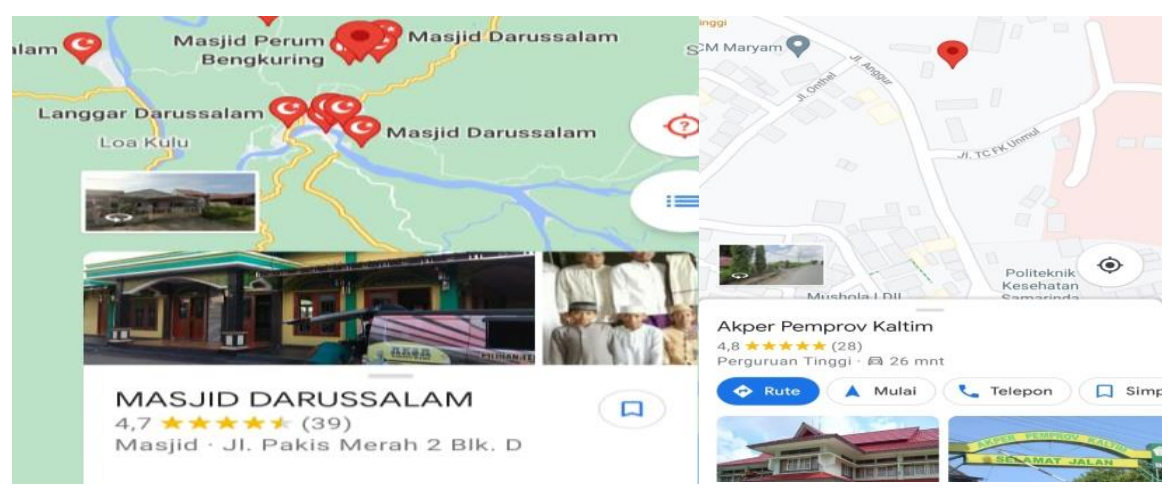

Gambar 1. Peta lokasi asal jamaah masjid dan tempat kegiatan pengabdian masyarakat 


\section{METODE}

Pengabdian masyarakat dilaksanakan pada tanggal 23 Juni 2021 Waktu kegiatan berlangsung pukul 09.00 sd 14. WITA di Minihospital Prodi D3 Keperawatan FK Unmul (eks Akper Pemprov Kaltim). Sasaran pengabdian masyarakat adalah anak-anak jamaah masjid Darussalam Bengkuring Samarinda sebanyak 14 anak. Metode yang digunakan meliputi tahapan persiapan, pelaksanaan dan evaluasi. Metode evaluasi keberhasilan hipnoterapi diukur dengan ekspresi anak dan hasil wawancara pada anak.

a. Tahap persiapan

1) Penerapan protokol kesehatan(Kementerian Kesehatan Republik Indonesia, 2020): anak dan orang tuanya mencuci tangan menggunakan handsanitizer(Dyan Kunthi Nugrahaeni, Novie Elvinawaty Mauliku, Budiman Budiman, Gunawan Irianto, 2021), di ukur suhu tubuhnya dan membagikan masker jika belum memakai masker

2) Orang tua mendapat penjelasan prosedur sirkumsisi

3) Orang tua menandatangani inform consern

4) Mengumpulkan anak anak dalam ruangan, dilakukan rileksasi dan diberikan sugesti agar anak anak tidak cemas dan berani di sirkum (sunat). Saat anak anak rileks ditanamkan anchor agar saat akan dihipnosis menjelang penyuntikan mudah mengalami rileks

b. Tahap pelaksanaan

Proses berlangsungnya kegiatan pengabdian masyarakat sebagai berikut:

1) Alat dan bahan disiapkan di rungan.

2) Anak yang akan disirkum di jemput untuk memasuki ruangan sirkumsisi.

3) Anak yang akan disirkum diletakan pada tempat tidur yang sudah disiapkan.

4) Menanyakan pada anak apakah ingin sunat yang sakit atau tidak, saat menjawab tidak maka ikuti kata kata Om (hipnoterapis) dan lakukan yes set minimal 3 kali.

5) Anak yang akan disirkum dilakukan hipnosis dengan mengaktifkan anchor yang sudah dipasang (Budiman, 2017)

6) Melakukan deepening untuk memperdalam kondisi hipnosis anak dengan menghitung mundur dari 10 sampai 1 atau menjatuhkan tangan ke kasur. (Danang Tri Yudono, Noor Yunida Triana, 2014)

7) Memberikan sugesti : saat saya mengoleskan obat (alcohol) pada burung adik maka akan terasa dingin sehingga daerah yang dingin tidak merasakan nyeri/nyerinya hilang, jika adik paham anggukan kepala atau katakan ya. Jika anaknya mengangguk atau berkata ya maka hipnoterapis mengoleskan alcohol pada penis dan daerah sekitarnya sambil memberikan sugesti kulit yang dingin sudah tidak merasakan nyeri.

8) Lakukan uji coba dengan menjepit ujung penis (kulup) dengan pinset atau cubitan, jika tidak merasakan nyeri maka sugesti hipnosis berhasil.

9) Operator menyuntik abat anestesi pada tempat yang seharusnya.

10) Operator mencoba ulang keberhasilan anestesinya dengan menjepit ujung penis dengan klem

11) Operator melaksanakan prosedur sirkumsisi.

12) Saat operator melaksanakn sirkumsisi, hipnoterapis memberikan sugesti pada anak untuk bermain olah raga yang disenangi atau game yang disenangi

13) Anak dibangunkan setelah operator selesai sirkumsisi. 


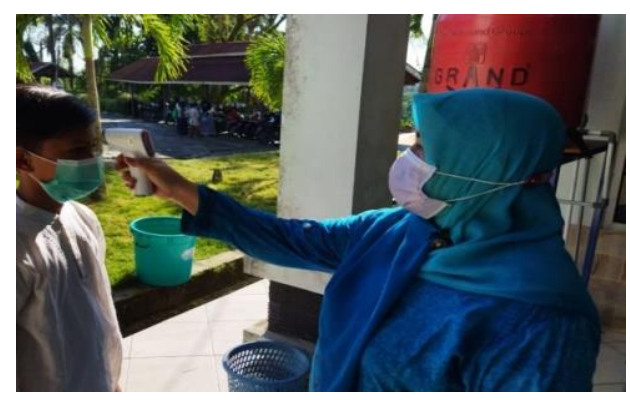

Gambar 1. Mengukur suhu tubuh

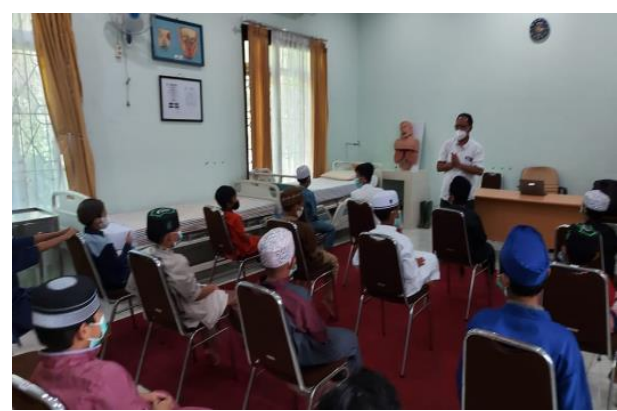

Gambar 3. Bina hubungan saling

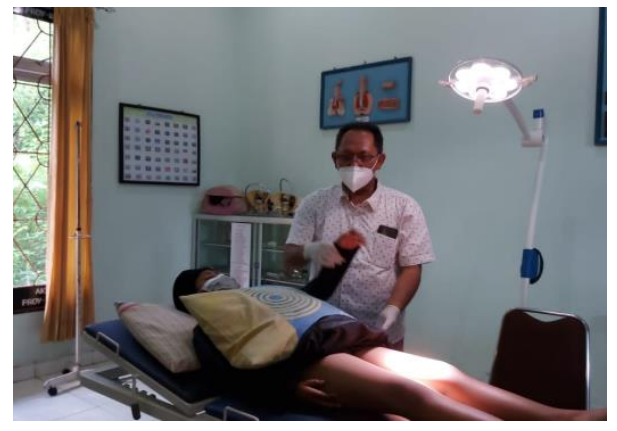

Gambar 5. Proses hipnosis

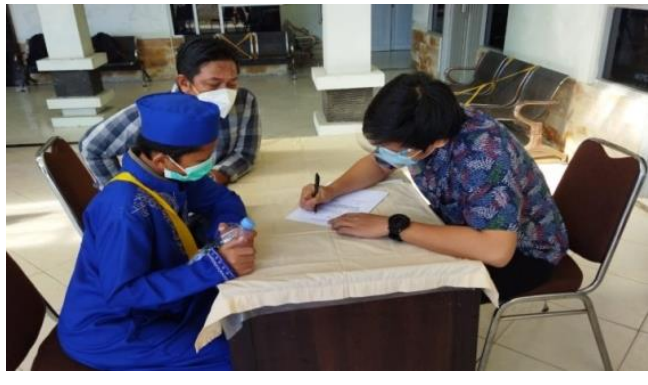

Gambar 2. Penjelasan prosedur sirkumsisi dan tanda tangan inform consent

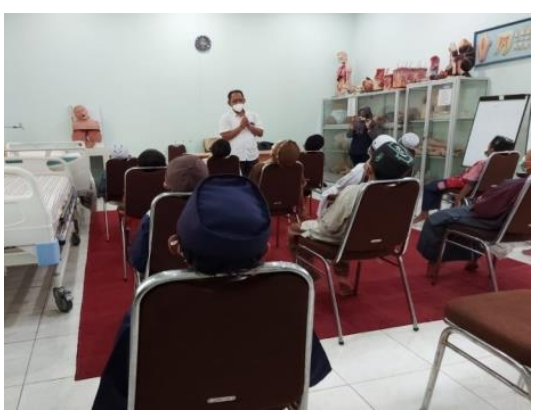

Gambar 4. Rileksasi dan sugesti

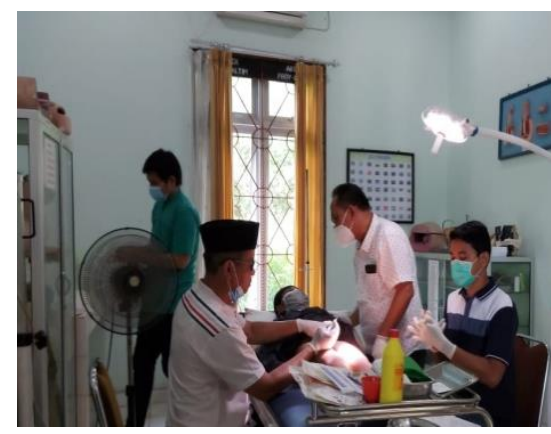

Gambar 6 . Proses sirkumsisi

\section{c. Evaluasi kegiatan hipnosis saat sirkumsisi}

Evaluasi dilakukan untuk mengetahui keberhasilan proses hipnosis saat penyuntikan obat anestesi melalui ekspresi wajah dan wawancara setelah prosedur sirkumsisi selesai

\section{HASIL DAN PEMBAHASAN}

Hasil pengukuran ekspresi wajah: Pengukuran nyeri menggunakan visual analoque scale dengan nilai rata rata 0 karena setelah di hipnosis, saat anak di suntik anestesi tidak berespon, anak tampak tenang tidak meringis kesakitan. Respon yang ditimbulkan anak pada saat nyeri berupa menyeringai, dahi berkerut, merengek, menangis dan berteriak sampai berontak (VellyzaColin, Buyung Keraman, Dian Dwianamaydinar, 2020). Beberapa anak sebelum dilakukan hipnoterapi menujukan ekpresi takut dan berontak. Hipnoterapist mempersiapkan kondisi hipnosis dengan mengumpulkan anak anak dalam ruangan, dilakukan rileksasi dan diberikan sugesti agar anak anak tidak cemas dan berani di sirkum (sunat). Saat anak anak rileks ditanamkan anchor agar saat akan dihipnosis menjelang penyuntikan mudah mengalami rileks. 
Hasil pengukuran wawancara : Anak anak tidak merasakan sakit saat disuntik dan proses sirkumsisi. Anak yang sedang dihipnosis maka anchor akan aktif. Jenis anchor yang diberikan adalah dengan menepuk pundak kiri sambil bilang tidur. Anak langsung tertidur seperti rileks. Anchor adalah berbagai pemicu visual, auditori dan kinestetik yang terhubung dengan respons atau kondisi emosi (emotional state) tertentu, selalu tersedia pada diri manusia dan akan berespon tanpa berpikir, jangkar emosi ini akan menstimulasi anak pada kondisi emosional yang semula takut akan disuntik anestesi berubah menjadi kondisi siap untuk anestesi (P.Putra, 2010). Anchor tepukan/sentuhan berarti kondisi terdistraksi, hal ini memicu anak beralih perhatian dari nyeri sehingga nyeri berkurang(VellyzaColin, Buyung Keraman, Dian Dwianamaydinar, 2020). Anak anak berani untuk dilakukan sirkumsisi dan orang tua senang karena anaknya tidak menangis dan berani disunat karena tidak sakit. Orang tua akan merasa tenang dan nyaman ketika anak yang mengalami nyeri dapat mengontrol kondisinya. Stressor nyeri dirasakan stressor orang tua juga. Kondisi tenang dan nyaman yang dirasakan anak berdampak pada suasana tenang pada orang tua dan kecemasan orang tua berkurang. (Apriany, 2013)

\section{KESIMPULAN DAN SARAN}

Pengabdian masyarakat penerapan hipnosis saat intraoperative sirkumsisi mampu menghilangkan nyeri saat penyuntikan obat anestesi. Diharapkan hipnosis dapat diterapkan saat pelaksanaan sirkumsisi sebagai pilihan utama manajemen nyeri pada sirkumsisi.

\section{DAFTAR PUSTAKA}

Apriany, D. (2013). Hubungan Antara Hospitalisasi Anak dengan Tingkat Kecemasan Orang Tua. Jurnal Keperawatan Soedirman, Vol. 8(No. 2), 92104.

http://jks.fikes.unsoed.ac.id/index.php/jks/article/view/185/86gmbran

Birnie, Kathryn and Noel, Melanie and Parker, Jennifer and Chambers, Christine and Uman, Lindsay and Kisely, Steve and McGrath, P. (2014). Systematic Review and Meta-Analysis: Distraction and Hypnosis for Needle-Related Pain and Distress in. Ournal of Pediatric Psychology, 39(8), 783-808.

Budiman. (2017). Efektivitas hypnoterapi teknik anchor terhadap perubahan perilaku merokok remaja studi pada klien di klinik Maulana center of hypnotherapy Palembang. Psikis: Jurnal Psikologi Islami, 2(2), 135-148.

Cahyadi, A. (2017). Metode hipnoterapi dalam merubah perilaku. 17, 73-82.

Danang Tri Yudono, Noor Yunida Triana, M. M. (2014). Pengaruh hipnoterapi terhadap nyeri pada pasien dispepsia di RSUD dr. R. Goeteng Taruna Dibrata Purbalingga 1. Viva Medika, 07(13), 65-76.

Dyan Kunthi Nugrahaeni, Novie Elvinawaty Mauliku, Budiman Budiman, Gunawan Irianto, A. N. (2021). Partisipasi dalam pencegahan dan penanggulangan Covid-19. JKPKM, 4(4), 941-953.

Fachri AH. (2008). The Real Art Of Hypnosis (Z. . N. Er. Hidayat (ed.); 1st ed.). Gagas Media.

Kementerian Kesehatan Republik Indonesia. (2020). Protokol kesehatan bagi masyarakat di tempat dan fasilitas umum dalam rangka pencegahan dan pengendalian corona virus disease 2019 (covid-19). Peraturan Menteri 
Kesehatan Republik Indonesia, Nomor 9(Pedoman Pembatasan Sosial Berskala Besar dalam Rangka Percepatan Penanganan Corona Virus Dlsease 2019 (COVID-19)), 2-6. http: / /jurnalrespirologi.org/index.php/jri/article/view/101

P.Putra, Y. (2010). Rahasia di balik Hipnosis Ericksonia dan Metode Pengembangan Pikiran lainnya.Jakarta. PT Elex Media KomputindoGramedia.

Samsugito, I. (2020). Pengaruh Hipnosis Dalam Mengurangi Nyeri Saat. Jurnal Medika Karya Ilmiah Kesehatan, 5(2).

Soma Arabzade Moghadam, Fayegh Yousefi, S. S. (2021). The effect of hypnosis on pain relief due to injection of dental infiltration anesthesia. Clin Exp Dent Res, 7(3), :399-405.

Syamsul, I. (2019). Pengaruh teknik distraksi dengan melihat dan memegang Nald terhadap intensitas nyeri pada pasien yang dilakukan penyuntikan anestesi sirkumsisi di Medan. Tesis. repositori.usu.ac.id/handle/123456789/20730.

VellyzaColin, Buyung Keraman, Dian Dwianamaydinar, M. P. (2020). Pengaruh teknik distraksi menonton kartun animasi terhadap penurunan skala nyeri saat injeksi pada anak usia pra sekolah. Jurnal Keperawatan Muhammadiyah Bengkulu, 08(1), 43-50.

Wahyuni Hesti, Setiawaty, I. I. (2015). Terapi Slow Deep Breathing Dengan Bermain. Skolastik Keperawatan, 1(2), 36-43. 